\title{
A terra dos coronéis no Oeste do Brasil: A cattle frontier, violência e dominação fundiária no Cerrado goiano
}

\author{
Sandro Dutra e Silva* \\ Talliton Tulio Rocha Leonel de Moura** \\ Francisco Itami Campos***
}

\section{RESUMO}

As questôes fundiárias do Oeste do Brasil foram marcadas pela dominação e violência na história da ocupação da fronteira. Diferente do texto clássico de F. J. Turner em que a disponibilidade de terras livres na fronteira motivou, não apenas a ocupação do Oeste mas também foi elemento fundamental para a construção da identidade americana (individualismo e democracia), este artigo apresenta as características de isolamento, pobreza estrutural e violência, que marcaram a fronteira no Meio-Oeste brasileiro. Assim, baseados na Western History e no conceito clássico de fronteira, bem como nas apropriaçóes desse conceito pela historiografia brasileira, propomos identificar, por meio da análise documental e em fontes secundárias o estudo da relação entre sociedade, história e natureza na fronteira goiana, com ênfase na cattle frontier e na dominação fundiária que marcou a regiáo entre a segunda metade do século XIX e a primeira metade do século XX.

Palavras-chave: fronteira Goiás; Oeste brasileiro; pecuária; história do Oeste; dominação fundiária.

\section{ABSTRACT}

Land issues in Western Brazil were marked by domination and violence during the history of the frontier's occupation. Unlike the classic text of F. J. Turner, where the availability of free

Artigo recebido em 21 de outubro de 2014 e aprovado para publicação em 21 de março de 2015.

DOI - http://dx.doi.org/10.1590/2237-101X016030009

* Doutor em História Social pela Universidade de Brasília (UnB), professor titular do Centro Universitário de Anápolis (UniEVANGELICA) e professor titular da Universidade Estadual de Goiás (UEG). Goiânia, GO, Brasil. E-mail: sandrodutr@hotmail.com.

** Mestrando do Programa de Pós-Graduação em Territórios e Expressôes Culturais do Cerrado, pela Universidade Estadual de Goiás (UEG). Anápolis, GO, Brasil. E-mail: tallitontulio@gmail.com.

*** Doutor em Ciência Política pela Universidade de São Paulo (USP), professor titular (aposentado) na Universidade Federal de Goiás (UFG) e professor no Centro Universitário de Anápolis (UniEVANGÉLICA). Goiânia, GO, Brasil. E-mail: itamicampos@unievangelica.edu.br. 
Sandro Dutra e Silva, Talliton Tulio Rocha Leonel de Moura e Francisco Itami Campos

land in the frontier motivated not only the occupation of the West, but also represented a key element for the construction of the North-American identity (individualism and democracy), this paper presents the characteristics of isolation, structural poverty and violence that marked the Brazilian Midwest frontier. Thus, based on Western History and on the classical concept of frontier, as well as its appropriations by the Brazilian historiography, we propose to study, through documentary analysis and secondary sources, the relationship between society, history and nature in the Goiás frontier, with emphasis on the cattle frontier and land dominance that marked the region between the second half of the nineteenth century and the first half of the twentieth century.

Keywords: Goiás frontier; Midwestern Brazil; Livestock; Western history; Land domination.

\section{Introdução}

A história do Oeste brasileiro tem sido interpretada por meio de diferentes categorias historiográficas, entre as quais a de fronteira. Essa categoria é utilizada em estudos que envolvem história e natureza. De acordo com David McCreery, ${ }^{1}$ o conceito de fronteira aparece pouco nas interpretaçôes históricas, tanto no Brasil como na América Latina. A quase ausência dessa categoria na tradição historiográfica brasileira deve-se, em grande parte, à compreensão dela tanto na América Latina quanto no Brasil, entendida como divisa territorial. $\mathrm{O}$ autor argumenta que o conceito de sertão tem sido mais empregado no Brasil, compreendido como categoria que mistura ficção e realidade. As diferenças entre fronteira e sertão decorrem das formas distintas de perceber o território e as relaçôes entre história, sociedade e natureza, pois se para "[...] a tradiçáo norte-americana a fronteira tinha conotaçôes de oportunidade, de um lugar para começar de novo, para os brasileiros o sertão era um espaço escuro, desconhecido e perigoso, sem Deus, sociedade ou Estado". ${ }^{2}$

Esse aspecto também é destacado pelo historiador americano Walter Prescott Webb, ${ }^{3}$ que reforça os diferentes sentidos que assumem esse termo na Europa e nos Estados Unidos. $\mathrm{Na}$ concepção europeia, fronteira está ligada às linhas divisórias que separam diferentes territórios e estados nacionais, sentido que deixou heranças na forma de compreensão latino-americana, enquanto que, nos Estados Unidos, fronteira assume significado diferente:

\footnotetext{
${ }^{1} \mathrm{O}$ pesquisador David McCreery fez uma pesquisa historiográfica com uma extensa base de dados documentais sobre o período Imperial em Goiás (1822-1889), em que utilizou o conceito de fronteira para caracterizar o distanciamento e o isolamento da província goiana em relação às demais regiôes do país. Ver: McCREERY, David. Frontier Goiás, 1822-1889. Stanford, California: Stanford University Press, 2006.

${ }^{2}$ Whereas in the North American tradition the frontier had connotations of opportunity, of a place to start over, for Brazilians the sertão was a dark, unknown, and dangerous space, without God, society, or the state (tradução livre do autor). McCREERY, David, ibidem, p. 15.

${ }^{3}$ WEBB, Walter Prescott. The Great Frontier. Reno, Las Vegas: University of Nevada Press, 2003.
} 
Sandro Dutra e Silva, Talliton Tulio Rocha Leonel de Moura e Francisco Itami Campos

$\mathrm{O}$ americano considera a fronteira como encontrando-se dentro desse espaço, não à borda ou nos limites de um país. Não é uma linha impeditiva à passagem, mas uma área convidativa à entrada. Em vez de ter apenas uma única dimensão, o comprimento, como na Europa, a fronteira americana tem duas dimensóes, o comprimento e a largura. Na Europa, a fronteira está, presumivelmente, permanentemente estacionada; na América ela era transitória e temporal. ${ }^{4}$

Apesar dessas nuances conceituais, podemos destacar um conjunto de pesquisadores brasileiros que tem se apropriado desse conceito. Muitos desses autores se aproximam da concepção americana, utilizando o conceito de fronteira como importante categoria analítica na compreensão histórica entre indivíduos e o meio natural. Posicionamo-nos nesse grupo por considerar que o uso dessa categoria interpretativa abre ricas possibilidades na compreensão da relação entre sociedade, história e natureza no Oeste brasileiro.

O objetivo deste texto é analisar a dinâmica da vida social em Goiás, marcada pelas condiçôes de fronteira, no período compreendido entre as primeiras décadas do século XIX e início do século XX. Nesse período, a pecuária extensiva era a principal atividade econômica nas savanas do Oeste do Brasil. ${ }^{5}$ Ela garantia a apropriação das terras pelas elites locais e caracterizava uma cattle frontier ${ }^{6}$ em Goiás.

Vale destacar que a base teórico-metodológica para esse exercício interpretativo é a tradição americana da Western History, ${ }^{7}$ sobretudo nos estudos que utilizam as categorias frontier

\footnotetext{
${ }^{4}$ The American thinks of the frontier as lying within, and not at the edge of a country. It is not a line to stop at, but an area inviting entrance. Instead of having one dimension, length, as in Europe, the American frontier has two dimensions, length and breath. In Europe, the frontier is stationary and presumably permanent; in America, it was transient and temporal (tradução livre do autor). WEBB, Walter Prescott. Ibidem, p. 2-3.

${ }^{5}$ As áreas de savana no Cerrado goiano favoreceram o desenvolvimento da atividade pecuária na região central do Brasil. A abundância de gramínea nativa dos "campos cerrados" e a facilidade em escoamento da produção por meio de tropeiros e boiadeiros permitiram a sustentabilidade desta atividade econômica, que se tornou a principal entre o final do século XVIII e a primeira metade do século XX. Já na primeira metade do século XX iniciou-se a construção da ligação ferroviária com o Sudeste brasileiro, favorecendo a migração para o território goiano e a valorizaçáo de terras mais próprias para a agricultura. Essas terras compreendiam as áreas de floresta tropical conhecida como Mato Grosso de Goiás, desprezada pela atividade da pecuária. Sobre a expansão agrícola e colonização do Mato Grosso de Goiás ver: SILVA, Sandro Dutra e. Os estigmatizados: distinções urbanas às margens do rio das Almas em Goiás (1941-1959). Tese (Doutorado em História). Programa de Pós-Graduação em História. Universidade de Brasília, Brasília, 2008.

${ }^{6}$ Sobre a Cattle Frontier ver: HENNESSY, Alistair. The Frontier in Latin American History. Londres: Edward Arnold, 1978; McCREERY, David, op. cit.

${ }^{7}$ De acordo com o historiador Arthur Ávila a Western History é um campo historiográfico norte-americano dedicado à história do Oeste e da fronteira. O autor afirma que esse campo historiográfico inicialmente confundia a história da fronteira como uma história nacional e atualmente busca a compreensão de fenômenos regionais. Sobre a Western History e o processo de "marginalização" desta como história nacional para o regional ver: ÁVILA, Arthur Lima. Da história da fronteira à história do Oeste: fragmentação e crise na Western history norte-americana no século XX. História Unisinos, v. 13, n. 1, p. 78-83, jan./abr. 2009.
} 
Sandro Dutra e Silva, Talliton Tulio Rocha Leonel de Moura e Francisco Itami Campos

e wilderness. ${ }^{8}$ Essa tradição envolve não apenas a relação entre a sociedade e natureza, que é o debate central dos historiadores ambientais, mas os temas diversos que caracterizam os estudos dos "historiadores do oeste". O historiador americano Donald Worster" apresenta essa pluralidade de abordagens na Western History, posicionando-se, assumidamente, como um historiado do oeste. Segundo o autor, existe ainda uma gama ampla de temas a serem abordados pelos historiadores interessados nos estudos do oeste, com um universo amplo de debates em que a fronteira assume diferentes dimensóes. Worster cita como exemplo as abordagens de Henry Nash Smith ${ }^{10}$ sobre os símbolos e os mitos do oeste. ${ }^{11}$ Argumenta, no entanto, que o enfoque do seu trabalho, em particular, está na relação entre a história e a natureza. A opção em utilizar nessa análise os pressupostos da tradição americana nos estudos da fronteira justifica-se por ser a Western History uma referência que nos permite uma melhor analogia ao contexto goiano. Ainda, porque nos permite ampliar o debate historiográfico dos estudos regionais em Goiás, geralmente centrados na tradição da teoria social europeia, como as do estruturalismo e da tipologia da dominação. Assim, os trabalhos em Goiás que utilizaram como temas o poder local, coronelismo, dominação fundiária e violência seguiram uma linha interpretativa em que as condiçôes da frontier/wilderness não figuravam como base interpretativa. ${ }^{12}$ Este artigo não tem a pretensão de questionar o valor teórico-metodológico da tradição europeia nos estudos historiográficos em Goiás. Além disso, a nossa intenção aqui não é realizar um estudo comparado do caso norte-americano e a tese clássica da fronteira com a fronteira em Goiás. O nosso objetivo central é buscar uma aproximação com os pressupostos dos estudos da fronteira para uma análise interpretativa da história goiana, considerando como objetos de investigação as questôes envolvendo poder local, latifúndio e violência nos vastos sertôes da fronteira do gado em Goiás. Para tanto, a

\footnotetext{
${ }^{8}$ Sobre os temas da fronteira e natureza na tradição americana existem várias obras que tiveram como base o texto clássico de F. J. Turner (TURNER, Frederick Jackson. The frontier in American history. Mineola, Nova York: Dover Publications, 2010). Podemos citar, além do próprio Turner: CRONON, William. Uncommon Ground: Rethinking the Human Place in Nature. Nova York/Londres: W. W. Norton \& Company, 1996; NASH, Roderick Frazier. Wilderness and the American Mind. New Haven/Londres: Yale University Press, 1982; SMITH, Henry Nash. Virgin Land: the American West as Symbol and Myth. Cambridge, Massachusetts/Londres, Inglaterras: Harvard University Press, 2009; WEBB, Walter Prescott. The Great Frontier, op. cit.; WORSTER, Donald. Under Western Skies: Nature and History in the American West. Nova York: Oxford University Press, 1992.

${ }^{9}$ WORSTER, Donald, op. cit.

${ }^{10}$ SMITH, Henry Nash, op. cit.

${ }^{11}$ Idem.

${ }^{12}$ Sobre os estudos que envolvem relaçóes de poder em Goiás, ver: PALACIN, Luís. Coronelismo no extremo norte de Goiás: o padre João e as três revoluçôes de Boa Vista - Tocantinópolis. São Paulo: Ediçóes Loyola, 1990; PALACIN, Luís. O século do ouro em Goiás: 1722-1822, estrutura e conjuntura numa capitania de Minas. Goiânia: Ed. da UCG, 1994; CAMPOS, Francisco Itami. Coronelismo em Goiás. Goiânia: UFG, 2003; BORGES, Barsanufo G. O despertar dos dormentes. Goiânia: editora da UFG, 1980; CHAUL, Nasr Fayad. Coronelismo em Goiás: estudo de casos e famílias. Tese (Mestrado em História). Goiânia: Kelps, 1998; SOUZA, Dalva Maria Borges de Lima Dias de. Violência, poder e autoridade em Goiás. Goiânia: Editora UFG, 2006.
} 
Sandro Dutra e Silva, Talliton Tulio Rocha Leonel de Moura e Francisco Itami Campos

cattle frontier e as suas implicações em relação ao poder local, às questôes agrárias e a violência como traço cultural são analisadas a partir da referência e da apropriação do conceito na tradição americana da Wertern History, em sua relação com a história e a natureza em Goiás, Centro-Oeste do Brasil.

\section{A cattle frontier em Goiás: os senhores de gado e as questóes fundiárias}

De acordo com Ávila, nas décadas de 1940 e 1950 a Western History passou a sentir uma sensível mudança de foco, contribuindo para o que ele definiu como a emergência de "consciência regional" ${ }^{13} \mathrm{O}$ resultado dessa transformaçáo foi que a historiografia do oeste buscava a revisão da concepçáo turneriana da fronteira, questionando, contextualizando e trazendo novos olhares para a tese clássica e mais atraente na historiografia americana. A partir daquele momento a historiografia procurou se envolver mais com a temática local em detrimento das explicaçóes nacionais da fronteira. ${ }^{14}$ Esse período mais "regionalista" náo significava um abandono da temática da fronteira, mas procurava romper com as interpretaçóes generalistas de uma história nacional da fronteira. As décadas de 1980 e 1990 foram marcadas por uma retomada do tema por meio da chamada New Western History. Ávila nos adverte que apesar dos novos historiadores do oeste manterem uma posição de resistência à visão "heurística" do conceito de fronteira em termos turnerianos, o campo historiográfico parecia incapaz de fornecer aportes teórico-metodológicos que fosse capaz de servir como chave interpretativa para o próprio Estados Unidos como para todas as Américas. ${ }^{15}$ Entre crises, deslocamentos e renascimentos, o conceito de fronteira ainda mantém o seu valor interpretativo. Assim, nos posicionamos em concordância com Alistair Hennessy, que defende adaptaçôes necessárias para o uso do conceito de fronteira nas interpretaçóes históricas, especialmente para o caso latino-americano. Para Hennessy, o mito da democracia e a sua relação com a fronteira não se aplicam à América Latina por duas razóes em especial: (i) o modelo linear de ocupação americana se difere do modelo de hollow frontier (fronteira oca) do caso latino-americano, significando diferentes maneiras de ocupar o território; (ii) a fronteira na América Latina, em vez de constituir modelos democráticos, intensificava o poder local e seu sistema de domínio fundiário. ${ }^{16}$

Esse foi o caminho utilizado pelo historiador americano David McCreery como modelo interpretativo em sua obra Frontier Goiás. ${ }^{17}$ Suas análises são referências fundamentais para

\footnotetext{
${ }^{13}$ ÁVILA, Arthur Lima, op. cit.

${ }^{14}$ Uma importante contribuição para esse debate é a obra de Donald Worster (op. cit.), sobretudo nos capítulos intitulados "Beyond the Agrarian Myth" e "New West, True West". WORSTER, Donald, op. cit.

${ }^{15}$ Ibidem, p. 94.

${ }^{16}$ HENNESSY, Alistair, op. cit.

${ }^{17}$ McCREERY, David, op. cit.
} 
Sandro Dutra e Silva, Talliton Tulio Rocha Leonel de Moura e Francisco Itami Campos

a ampliação dos estudos sobre a relação entre sociedade, território e natureza na fronteira em Goiás. Esse historiador procurou dialogar tanto com a tradição historiográfica brasileira, quanto com tradição americana, e também com as interpretaçôes do inglês Hennessy (1978) sobre a fronteira na América Latina. A fronteira Goiás foi analisada a partir da coleta e estudo de significativa base documental sobre a província goiana (1822-1889). A tese central era que o território goiano situava-se nos limites do mundo moderno do século XIX. A província de Goiás era a "fronteira da fronteira", devido ao seu isolamento territorial e político, às dificuldades de acesso e à estagnaçáo econômica herdada da escassez da mineração de ouro no final do século XVIII. Para ele, além desses fatores histórico-geográficos, outros elementos contribuíram para essa condição periférica, tais como frequentes ataques indígenas e de jagunços que aterrorizavam fazendas e vilarejos em Goiás.

A precária estrutura de poder foi uma das principais características da fronteira goiana, cuja administração pública era baseada no personalismo e na dominação fundiária, com poucas possibilidades de desenvolvimento econômico. A falta de estradas tornava a região um espaço isolado, distante do poder central. As ligaçóes da Corte com o planalto central do Brasil se davam por rotas de tropeiros. A pecuária era a atividade econômica que mais se adaptava às condiçóes da fronteira, dadas as formas de transporte e manejo das boiadas. Essas condiçóes da fronteira resultaram na emergência de processos de desumanização nas relaçóes entre os indivíduos que viviam no isolamento do distante Oeste do Brasil.

O conceito de fronteira foi a opçâo teórica que o autor utilizou para desenvolver a sua reflexão sobre Goiás, visto como a fronteira mais longínqua do império (the frontier of the frontier). A fronteira em Goiás era o lugar de ameaças, perigos, conflitos e dominação. Os senhores de terra e de gado em Goiás assumem, nessa análise, significativo valor interpretativo, considerando as proporçôes continentais do território brasileiro e as articulaçóes entre o império brasileiro e as elites locais, como forma de garantir a integridade territorial e a autonomia fiscal na fronteira: "No dia a dia, o Estado era representado pela elite local, a quem a população sempre devia obediência: $\mathrm{O}$ príncipe reina com a ajuda dos senhores da terra, que são os que governam" ${ }^{18}$ Além disso, a fronteira representava as condiçôes de exclusão e pobreza que atingia todos os segmentos sociais. A pobreza e a ineficiência do Estado em instituir um sistema de coesão social fizeram com que a regiáo entrasse em uma condição permanente de desumanização. Todos estavam sujeitos a situação de precariedade e de escassez, fossem eles coronéis, camponeses ou indígenas. Até mesmo o mais abastado dos cidadãos sofria as consequências do isolamento no distante oeste.

McCreery recorre ao conceito de cattle frontier como referência à estrutura econômica e de dominação política em Goiás. Ele considera a base econômica pelo prisma da atividade pecuária, que se apresentava como principal fonte econômica em Goiás. A terra não se apresentava como critério de riqueza, por ser a quase totalidade do território considerado como

\footnotetext{
${ }^{18}$ Ibidem, p. 3.
} 
Sandro Dutra e Silva, Talliton Tulio Rocha Leonel de Moura e Francisco Itami Campos

"terra devoluta", com a criação de gado se desenvolvendo livremente sobre esse território "sem donos". Os territórios indígenas constituíam uma exceção e uma ameaça ao mesmo tempo, pois na porção sudoeste da província estava localizada a nação Caiapó e ao norte e noroeste as possessóes xavantes.

Os senhores de gado compunham a elite da fronteira, sendo responsáveis pelo controle do poder executivo, do judiciário e do legislativo. A atuação política dos coronéis se caracterizava pela defesa dos "interesses do Estado", que na verdade era a conjunção de interesses privados. Com um Estado fraco e inoperante, os senhores de gado executavam essas funçóes e agiam como autoridade, os donos do poder na fronteira. McCreery denominou essa forma de dominação de "despotismo pastoral", em que os coronéis, os senhores de gado, assumiam o controle das funçóes políticas e administrativas do Estado, abrindo estradas, construindo pontes e cuidando da segurança das cidades, legitimando com isso a sua função social como verdadeiros donos das terras e rebanhos.

O século XIX foi marcado por tipos específicos de violência que caracterizam a cattle frontier em Goiás. Reforçamos que a cattle frontier não é apenas uma forma econômica baseada na pecuária. Era um tipo específico de "pecuária de fronteira” em que outros elementos se inseriam, além do gado. A pecuária na fronteira oeste se diferenciava do sistema de produção característico do sul do Brasil, descrito pelo geógrafo brasilianista Stephen Bell como "Brazilian Ranching System". O geógrafo pesquisou a região da Campanha Gaúcha no sul do Brasil no período entre 1850 a 1920, apresentando um complexo sistema de produção do gado, que incluía melhoramento genético, uma organização produtiva da propriedade, processos de industrialização, logística entre outros sistemas produtivos com vistas ao mercado, interno e externo. ${ }^{19}$ A cattle frontier em Goiás mantinha as precárias estruturas de produção, aliadas a domínio fundiário em um vasto território de terras devolutas de campos cerrados. Assim, quando nos referimos à fronteira do gado em Goiás não levamos em consideração apenas a estrutura econômica, mas todas as relaçóes sociais e políticas que marcavam a condição de fronteira. $\mathrm{O}$ texto de $\mathrm{McC}$ reery serve de suporte na compreensão desse contexto, sobretudo no século XIX. Ao mesmo tempo, outras fontes, como relatos de viagens e outras narrativas, ${ }^{20}$ apresentam as condições sociais no distante sertão goiano. $\mathrm{O}$ relato de via-

\footnotetext{
19 Sobre o "Brazilian Ranching System" ver: BELL, Stephen. Campanha Gaúcha: a Brazilian Ranching System, 1850-1920. Stanford, California: Stanford University Press, 1998.

${ }^{20}$ Uma fonte privilegiada sobre o início do século XIX em Goiás e o cenário de isolamento da fronteira goiana são os registros do jornal Matutina Meiapontense, publicado em Meia Ponte (atual Pirenópolis) entre 1830 a 1834. O jornal foi uma iniciativa do comendador Joaquim Alves de Oliveira, citado por Saint-Hilaire em sua passagem por Meia Ponte. O naturalista francês hospedou-se em uma das fazendas do comendador, a Fazenda Babilônia, e destacava os ideais liberais do fazendeiro e comerciante goiano (SAINT-HILAIRE, Auguste de. Viagem à província de Goiás. Belo Horizonte: Itatiaia; Sáo Paulo: Editora da Universidade de São Paulo, 1975). O jornal publicou diferentes tipos de matérias, inclusive registros oficiais da província de Goiás. Foi uma das principais fontes utilizadas por David McCreery em sua coleta de dados. Esse material está disponível em formato digital.
} 
Sandro Dutra e Silva, Talliton Tulio Rocha Leonel de Moura e Francisco Itami Campos

gem deixado pelo naturalista francês Auguste de Saint-Hilaire (1779-1853), que percorreu a província de Goiás no início do século XIX, descreve o ambiente social na fronteira. Para Saint-Hilaire, a província de Goiás era um vasto sertão, não apenas pelas proporçóes territoriais imensas e com uma população dispersa, na vastidão do planalto central do Brasil, mas também pelo estágio de barbárie em que se apresentava:

Juntamente com a numerosa populaçáo que se estabelecera, como por artes mágicas, na regiáo de Goiás, vieram também os vícios mais terríveis. Bandos de criminosos tinham encontrado naquelas solidôes não só riquezas como também a impunidade, e no meio de uma sociedade em formação, onde ainda não existia polícia, eles podiam dedicar-se sem receio a todos os desregramentos. Em vão os magistrados tentavam fazer ouvir a sua voz, para reprimir as desordens. Tão corruptos quanto aqueles que deviam punir, eles só mereciam desprezo. As brigas se sucediam, e nenhum homem ousava encontrar-se com o outro sem estar armado, só deixando de lado as armas quando ia à igreja. ${ }^{21}$

A ocupação em Goiás esteve ligada, no início de sua colonização, à atividade mineradora do século XVIII. Passado o surto da exploração das lavras de ouro, a atividade pastoril tornou-se dominante. Antigos garimpeiros ou foram em buscas de novas minas, ou se fixaram nos ranchos para a criação de gado. Dessa forma, a atividade pastoril passou a ser predominante em Goiás no século XIX e no início do século XX. A atividade criatória fixou o morador na terra, na medida em que a produção aurífera na província não foi florescente e nem duradoura. A regiáo tinha uma baixa densidade demográfica, contando, em 1900, com 255.284 habitantes, o que contabilizava 0,40 habitante por $\mathrm{km}^{2}$. Em 1920, o censo registrou uma população de 511.919 habitantes, apresentando uma densidade demográfica de 0,8 habitante por $\mathrm{km}^{2}$. Em compensação, o censo registrava 2.841.081 cabeças de gado, numa razáo de 5,5 por habitante. Era um sertáo de gado, mais do que um sertão de gente. ${ }^{22}$

A pecuária se tornou, desde o final do século XVIII, a principal forma de ocupação, com o rebanho se distribuindo por todo o território goiano. Ela era fonte de riqueza e o maior fator de arrecadação de impostos, assim permanecendo em Goiás até os anos 1950. Essa atividade também permitia quebrar, parcialmente, o isolamento a que se circunscrevia a população goiana. $\mathrm{Na}$ inexistência de estradas e de meios de transporte, era o gado que se deslocava para o mercado mineiro ou paulista. ${ }^{23}$

Isolado e sem comunicação, com uma economia caracterizada como de subsistência ou natural, embora tivesse na pecuária a sua principal fonte de receita, assim o estado de Goiás

\footnotetext{
${ }^{21}$ SAINT-HILAIRE, Auguste de. Viagem às nascentes do rio São Francisco. Belo Horizonte: Itatiaia, 2004. p. $161-162$.

${ }^{22}$ CAMPOS, F. Itami. Questão agrária: bases sociais da política goiana (1930-1964). Tese (Doutorado em Ciências Políticas) - Departamento de Ciências Sociais, Universidade de São Paulo, USP, São Paulo, 1985.

${ }^{23}$ CAMPOS, Francisco Itami. Questôes agrárias: bases sociais da política goiana. Goiânia: Kelps, 2012.
} 
Sandro Dutra e Silva, Talliton Tulio Rocha Leonel de Moura e Francisco Itami Campos

se apresentava no final do século XIX e no início do século XX. Essa condição de fronteira criava grupos regionais que dominavam a região e chegavam a confrontar o poder estabelecido do Estado. O domínio fundiário para a atividade pastoril era, na maioria das vezes, marcado por violentos conflitos pela disputa da terra. Ou melhor, pela disputa de pastagens.

As condiçóes e os temas da fronteira do gado em Goiás se inserem no contexto apresentado por Oliveira ${ }^{24}$ como indícios da retomada do uso conceitual e a abordagem da frontier pela historiografia contemporânea que esteve associada ao campo da história ambiental nos Estados Unidos. Um exemplo dessa retomada sob o enfoque ambiental são os estudos de Donald Worster sobre o oeste. ${ }^{25}$ Worster se define como um historiador do Western, e que muitas vezes precisa definir que náo se trata de um historiador do mundo ocidental, mas de um local específico que é o American West. E dentro dos estudos do West é que as questóes que envolvem história e natureza são analisadas. A história ambiental assume em Worster uma posição privilegiada para a compreensão do oeste e da fronteira. Ele propóe, no entanto, ir além dos mitos da concepção clássica da fronteira, inclusive questionando sobre o real significado de oeste como território. Temas como mito agrário, ecologia pastoril (Cowboy eco$\log y)$, sociedade hidráulica, capitalismo agrícola, entre outros estudos, envolvem a discussão entre a fronteira, o oeste e a natureza. Sobre as questôes que envolvem a relação entre a história ambiental e a Western History o autor apresenta dois modos ecológicos primários (primary ecological modes) na ocupação da fronteira. O primeiro desses modos está relacionado com as atividades de pecuária e de pastoreio e o segundo relacionado com a agricultura, sobretudo no que se refere a atividades de plantio irrigado. Worster denomina esses sistemas como o "Oeste pastoril" e "Oeste hidráulico" (pastoral and the hydraulic West). ${ }^{26}$ Esses apontamentos figuram como suporte teórico fundamental na ampliação das análises da fronteira do gado em Goiás. Muito mais do que apenas descrever a atividade pecuária e suas características na ocupação territorial da província de Goiás, ela nos permite inserir novos elementos analíticos, sobretudo questóes que vão além da atividade do pastoreio.

A cattle frontier figura como um universo de possibilidades, incluindo estudos como: a expansão da atividade em um determinado ambiente, os recursos de gramíneas e pastagens disponíveis, a introdução de novas pastagens, a genética do gado introduzido, o cotidiano da atividade do vaqueiro, o papel do boiadeiro no transporte do gado para o mercado consumidor, o domínio do vasto território e as relaçóes de poder envolvidas, dentre outras. A história da pecuária no Brasil remonta ao século XVI e esteve vinculada, desde o início, ao processo de deslocamento para os sertóes. Em seu texto sobre a pecuária goiana, Odorico $\operatorname{Costa}^{27}$ reforça a tese de que os vaqueiros tiveram a mesma importância que os bandeiran-

\footnotetext{
${ }^{24}$ OLIVEIRA, Lucia Lippi. Americanos: representaçôes da identidade nacional no Brasil e nos EUA. Belo Horizonte: Editora UFMG, 2000.

${ }^{25}$ WORSTER, Donald, op. cit.

${ }^{26}$ Ver o artigo: New West, True West. In: WORSTER, Donald, ibidem, p. 19-33.

${ }^{27}$ COSTA, Odorico. A pecuária goiana. Cultura Politica: revista mensal de estudos brasileiros, Rio de Janeiro, ano IV, n. 46, p. 257-268, nov. 1944.
} 
Sandro Dutra e Silva, Talliton Tulio Rocha Leonel de Moura e Francisco Itami Campos

tes e desbravadores do sertão para a conquista geográfica da fronteira brasileira. O texto, escrito num período em que o regime nacionalista procurava reforçar elementos simbólicos para a justificativa da expansão agrícola no oeste, ${ }^{28}$ utilizava-se de referências como Basílio de Magalhães e Capistrano de Abreu para reforçar a tese de que vaqueiros e bandeirantes alargaram os limites territoriais brasileiros. Em suas palavras: "O curral de gado possui extraordinária situação na formação do Brasil. Ele foi sinal de passagem, foi evidência de posse e foi, ainda, tulha para a alimentaçấo. Foi um extraordinário instrumento de colonizaçâo". ${ }^{29}$ Odorico Costa considerava o vaqueiro como ator privilegiado na ocupação da fronteira, vindo após ele as fazendas, o engenho, o arraial e o efetivo povoamento das áreas interioranas.

$\mathrm{O}$ vaqueiro assume, nessa interpretaçáo, papel simbólico importante na conquista do sertão. Odorico procura reforçar o caráter heroico do vaqueiro descrevendo as suas atividades como elementos do ordinário, mas com função desbravadora como a dos bandeirantes. Dentre as atividades que cabiam ao vaqueiro na fronteira são destacadas pelo autor: amansar e domesticar o gado no sertão; evitar seu extravio na vastidáo sem cercas; curar os animais das pragas e vermes; marcar os bezerros; proteger os animais dos ataques das onças e das cobras; abrir bebedouros; e localizar áreas que servissem para a salitragem do gado, conhecidas como "barreiras" ou "lambedouros". No exercício desse ofício o autor relata a rusticidade da atividade pastoril, pois o vaqueiro teria que se isolar no ambiente hostil do cerrado, dormindo muitas vezes no campo junto com a boiada, principalmente durante o "inverno", que é como os moradores do Meio-Oeste do Brasil denominam o período chuvoso. Na invernada, que é um termo utilizado para descrever a abundância de pastagem e que coincide com o período chuvoso, o vaqueiro passava grande parte do seu tempo junto do gado, cuidando da bezerrada, pois era o momento em que ocorriam a maioria dos partos. ${ }^{30}$

No período de estiagem o vaqueiro precisava buscar novas pastagens em sua rotina de trabalho nas savanas do Brasil Central. Precisava atravessar o território, transpor rios, proteger o rebanho dos ataques indígenas e livrá-los de áreas dominadas por ervas daninhas. Nesse sentido a relação entre o vaqueiro e o sertão, no cenário da natureza hostil, constituía um elemento explicativo da rusticidade que era um elemento constituinte do seu ethos. Assim é que os elementos constituintes do ethos bandeirante, ${ }^{31}$ como o enfrentamento à natureza hostil e a sua função na conquista territorial do Oeste brasileiro, foram evidenciados no vaqueiro. Para Costa o vaqueiro teve relevante participação na formação nacional, comparando-o ao bandeirante da historiografia paulista: "Ele e o bandeirante se completam. O bandeirante era dinâmico. A sua função era a de devassar, de rasgar matas, de desbravar

\footnotetext{
${ }^{28}$ SILVA, Sandro Dutra e. O desbravador do Oeste: categorias e símbolos referenciais para a colonizaçáo de Goiás na Era Vargas. In: MARIN, Joel Orlando Bevilaqua; NEVES, Delma Pessanha (Org.). Campesinato e marcha para Oeste. Santa Maria, RS: Editora UFSM, 2013. p. 59-78.

${ }^{29}$ COSTA, Odorico, op. cit., p. 262.

${ }^{30}$ Idem.

${ }^{31}$ SILVA, Sandro Dutra e, 2013, op. cit.
} 
Sandro Dutra e Silva, Talliton Tulio Rocha Leonel de Moura e Francisco Itami Campos

chãos, de furar terras bárbaras ainda. $\mathrm{O}$ vaqueiro é estático. Agarra-se à terra e nela lança uma semente de civilização." ${ }^{2}$

$\mathrm{O}$ vaqueiro e o bandeirante se assemelham na conquista do território e no enfrentamento à natureza. $\mathrm{O}$ bandeirante minerador em Goiás acaba se transformando em vaqueiro após o esgotamento das minas de ouro. No entanto, não foi a migração do minerador em vaqueiro que introduziu a atividade pastoril em Goiás, haja vista que essa atividade esteve presente desde o início da ocupação na mining frontier. De acordo com Americano do Brasil, ${ }^{33}$ no final do século XVIII a pecuária goiana apresentava excelentes condiçóes e tornava-se uma atividade rentável e economicamente viável, na medida em que a mineração exigia maiores recursos e sacrifícios na sua extração. Os excelentes campos de cerrado favoreciam o desenvolvimento dessa atividade e, ao mesmo tempo, constituía novos senhores nas savanas centrais do Brasil. Da mesma forma, os ranchos e fazenda espalhavam-se pelos vastos territórios da província goiana. A fronteira do gado tomava forma e se caracterizava como a principal atividade em Goiás. As necessidades de expansão e domínio fundiário, associado a uma estrutura de força e dominação, com pouca presença do Estado, tornaram esse ambiente favorável para a constituição de situações em que a violência se torna naturalizada. ${ }^{34}$

Quando buscamos aplicação desses conceitos ao modelo goiano, ele segue a estrutura do oeste pastoril, baseado nas concepçóes da cattle frontier e nas assertivas de David McCreery. No entanto, esses fatores não identificam apenas uma relação entre história e natureza no sentido das fontes e dos recursos naturais. Ele aponta, ainda, para um vasto ambiente de adaptação e interação com o cenário natural. Nesse sentido, muito mais do que as questóes ecológicas que envolvem a adaptação à atividade pecuária nas savanas do planalto central brasileiro, outros temas se inserem nessa história do oeste. De acordo com Worster,

Os historiadores do Oeste não precisam se desesperar com este tema. Para aqueles com imaginação para encontrá-lo, há uma variedade densa de temas que podem ser, historicamente, escritos sobre esta região. Dentro de seus limites amplos e em todas as suas extensóes esparsas, através do qual se encontra uma duração de mais de 200 anos de colonização europeia e outros milhares de anos de vida aborígene, a região oferece para estudar toda a ganância, a violência, beleza, a ambição e variedade que todos podem se utilizar. Com tempo e esforço suficiente, quem sabe um dia poderá oferecer uma história de cuidado, a adaptação duradoura das pessoas na terra. [...] Estamos começando a conhecer onde é o verdadeiro Oeste, o que ele foi, o que ele poderia ter sido, o que ele ainda pode ser. Estamos começando a conhecer o lugar pela primeira vez. ${ }^{35}$

\footnotetext{
${ }^{32}$ COSTA, Odorico, op. cit., p. 263.

${ }^{33}$ BRASIL, Antônio Americano do. Súmula de História de Goiás. 3. ed. Edição anotada por Humberto Crispim Borges. Goiânia: Unigraf, 1982.

${ }^{34}$ McCREERY, David, op. cit.

${ }^{35}[. .$.$] the western historians need not despair of the West. For those with imagination to find it, there is plenty of$ thick history to be written about this region. Within its spacious boundaries and across its sparse, dry expanses,
} 
Sandro Dutra e Silva, Talliton Tulio Rocha Leonel de Moura e Francisco Itami Campos

A história e natureza como temas do oeste não se limitam a descriçóes meramente fitogeográficas ou agronômicas do território. Outros fenômenos de vida social se interagem a esse ambiente. A cattle frontier em Goiás, nesse sentido, se insere nesse vasto campo de abordagens que compóe a historiografia do Oeste brasileiro, ao fazer referências à estrutura econômica e à dominação política em Goiás durante o século XIX.

O século XX manteve a mesma estrutura da cattle frontier em Goiás. No entanto, algumas diferenças na situação de fronteira ocorreram, sobretudo na ampliação do sistema de transporte, com a chegada da ferrovia em $1912 .{ }^{36} \mathrm{~A}$ ferrovia, no entanto, resolve parte do isolamento, na medida em que ela se estende em parte do sul do estado. A partir dela foram se estabelecendo novas rotas rodoviárias e criando novas localidades na região da fronteira. Esse processo trouxe a valorização das propriedades, que outrora eram "terras devolutas". Essas grandes áreas de campo cerrado passaram a ser requeridas pelos coronéis em Goiás. Também impulsionou a migração para essa regiáo de fronteira, intensificando novos tipos de violência, tanto no campo como nas zonas urbanas em processo de expansão, como veremos adiante.

Um exemplo dessa nova forma de fronteira foram os relatos de Carlos Pereira de Magalhães, baseado em uma coletânea de cartas escritas entre 1918 a 1925, posteriormente publicadas com o título de "Cartas de Goias" ${ }^{37}$ Em uma carta datada de 8 de março de 1919, o advogado Carlos Pereira de Magalhães, vindo de Sáo Paulo com a finalidade de regularizar a documentação relativa à compra de grande área de terras em Goiás, descrevia aos seus superiores, membros de rica família paulista, a sua impressão sobre o sertão goiano: "esta gente goiana [...] tem como herança dos antepassados paulistas o heroísmo; quanto ao ambiente, é de combate, tanto se mata boi no matadouro como gente na chapada. A força do querer desta raça, quando despertada, é de ferro, para o bem o para o mal". ${ }^{38}$ Esse registro situa-se como indício da representação de isolamento e violência que caracterizava o distante Oeste brasileiro, nas fronteiras de Goiás. O advogado paulista descrevia com assombro aos Monteiro de Barros a violência que acometia o sertáo goiano, descrito por ele como o "Brasil grande e bárbaro". Magalhães referia-se a Goiás como um sertão segregado da civilização por dois séculos e que o contato com essa condição de fronteira despertava nele o "espírito sertanista”. O espírito sertanista dizia respeito ao seu estranhamento em relação ao ambiente natural e cultural. Ainda assim, apresentava-se a seus superiores como em missão sertanista, em funçáo da necessidade de reconhecimento das paisagens e da etnografia do hinterland

through what is now more than two hundred years of European settlement and many thousands of Indian life, this region offers for study all the greed, violence, beauty, ambition, and variety anyone could use. Given enough time and effort, it may someday also offer a story of careful, lasting adaptation of people to the land. [...] We are beginning to know where the true West is, what it has been, what it might have been, what it might still be. We are beginning to know the place for the first time (WORSTER, Donald, op. cit., p. 33).

${ }^{36}$ Sobre a expansão ferroviária em Goiás ver: BORGES, Barsanulfo, op. cit.

${ }^{37}$ MAGALHÃES, Carlos Pereira de. Cartas de Goiás no princípio do século XX. São Paulo: Editora De Letra em Letra, 2004

${ }^{38}$ Ibidem, p. 57. 
Sandro Dutra e Silva, Talliton Tulio Rocha Leonel de Moura e Francisco Itami Campos

brasileiro: "A nós, que elegemos este Estado para a aplicação de capital e trabalho, impóe-se como obrigação estudar e conhecer-lhe o ambiente. Como advogado que sou, as causas criminais e a delinquência, esse grande mistério, me atraem". ${ }^{39}$

Muitos dos relatos de Magalhães apresentavam as condiçóes naturais, os desafios da natureza hostil do Cerrado do Brasil Central, as ameaças das feras selvagens, o temor de constantes ataques indígenas e de cangaceiros, vindos do nordeste do país, e a violência cotidiana dos goianos. No entanto, os seus relatos têm um teor etnocêntrico, como este escrito em 14 de dezembro de 1918, em que afirmava que a vida noturna era dominada por jogatinas e que não existia a garantia de vida fora das ruas iluminadas, concluindo: "O ambiente social mantém padrôes que não estão à altura do nosso século. $\mathrm{O}$ homem genioso é de opiniáo, que vai às últimas consequências para sustentar sua palavra, embora absurda, é admirado". ${ }^{40}$ No cenário etnocêntrico de Magalhães, o ambiente e a sociedade, ou a natureza e a história, se misturavam. As paisagens gerais da distante fronteira goiana caracterizavam um Brasil vasto e bárbaro, em que as relaçóes sociais e a natureza hostil estabeleciam o tom das vivências nas savanas centrais do oeste. Escrita durante o período belicoso da Primeira Guerra Mundial, a carta chamava a atenção para o fato de que a violência não era traço cultural exclusiva do distante e bárbaro sertão: "Quando os povos que são o eixo do mundo e os pilares da civilização passam quatro anos em mútuo massacre, não admira que os povos atrasados se preparem para se entredevorarem". ${ }^{41}$

Além da violência cotidiana, um tipo de violência muito comum envolvia as relaçôes de trabalho e fundiárias em Goiás. Nesse quadro, inserem-se as relaçôes entre coronéis e camponeses, incluindo relaçôes de trabalho e a posse da terra. ${ }^{42}$ Neste contexto a ficçấo e a realidade pouco se diferenciam. Em um conto do escritor goiano Bernardo Élis podemos perceber uma pequena amostra dessa atmosfera social. Em "A enxada", o escritor goiano conta a trajetória de um camponês, Supriano ou Piano, que, por não ter nem posse da terra, nem os meios de produção, acabou por contrair dívidas com um poderoso senhor de terra. Esta condição o levou à servidão por dívida com um fazendeiro, o capitão Elpídio Chaveiro. Esse, por sua vez, destinou um lote de terra, já desmatado e queimado, para que Piano fizesse ali uma plantação. No entanto, não lhe disponibilizou as condiçôes necessárias para o plantio, faltando até mesmo a enxada para lavrar a terra. O conto de Bernardo Élis centra-se na luta desesperada do camponês em busca de uma enxada, e no seu temor em não conseguir entregar a lavoura plantada no prazo estipulado pelo fazendeiro, temendo as consequências

\footnotetext{
${ }^{39}$ Idem.

${ }^{40}$ Ibidem, p. 30

${ }^{41}$ Ibidem, p. 32

${ }^{42}$ Sobre esse tema ver: CAMPOS, Francisco Itami; SILVA, Sandro Dutra e. Coronéis e camponeses: a fronteira da fronteira e a tese da "ficção geográfica" em Goiás. In: SILVA, Sandro Dutra; PIETRAFESA, José Paulo; FRANCO, José Luiz de Andrade; DRUMMOND, José Augusto; TAVARES, Giovana Galvão. Fronteira Goiás: sociedade e natureza no Oeste do Brasil. Goiânia: Ed. da PUC Goiás, 2013. p. 39-54.
} 
Sandro Dutra e Silva, Talliton Tulio Rocha Leonel de Moura e Francisco Itami Campos

que poderiam vir. Bernardo Élis se apropria do realismo-naturalista e da forte carga de dramaticidade desse estilo literário. No conto, o lavrador Piano, após longa peregrinação e náo conseguindo a enxada para realizar o serviço, começa a lavar a terra com as próprias máos. Incapaz de cumprir o acordo, Piano tem a sua morte determinada pelo fazendeiro. Um capanga, também soldado do governo, ${ }^{43}$ foi designado para resolver o caso. $\mathrm{O}$ soldado desloca-se para a roça e se espanta com o cenário dramático: o camponês com os membros desfigurados, um molambo de gente cavando a terra seca para a plantação. No cumprimento das ordens dadas, o soldado mata o lavrador. Bernardo Élis descreve assim a cena:

Aí o soldado abriu a túnica, tirou debaixo um bentinho sujo de baeta vermelha, beijou, fez o pelo-sinal, manobrou o fuzil, levou o bruto à cara no rumo do camarada. [...] Do seu lugar, Piano meio que se escondeu por trás de um toco de peroba-rosa que não queimou, mas o cano do fuzil campeou, cresceu, tampou toda a sua vida, ocultou o céu inteirinho, o mato longe, a mancha por trás do soldado, que era o sol querendo romper as nuvens. ${ }^{44}$

A partir do realismo do conto de Bernardo Élis podemos conjecturar as possíveis formas de dominação que impunham as condiçóes de desumanização na fronteira. No entanto, além das questôes que caracterizavam o território, em suas articulaçôes políticas e geográficas, a fronteira era, ainda, uma condição cultural.

Um dos episódios mais dramáticos na história goiana e que torna evidente o clima de tensão e violência que se desenvolveu em Goiás, nas primeiras décadas do século XX, foi a chacina de São José do Duro, ocorrida no norte do estado em 1919. O episódio é um dos mais emblemáticos casos envolvendo duas oligarquias importantes em Goiás: os Caiados, grupo oligárquico do sul, e os Wolneys, coronéis do norte goiano. As disputas políticas entre o norte e o sul do estado sempre estiveram presentes no jogo de poder em Goiás. No entanto, as relaçôes entre os dois grupos se tornaram mais tensas quando Abílio Wolney e o senador Antonio Ramos Caiado se declaram inimigos. Todavia, o início da operação militar que culminou na chacina de parte da família Wolney em São José do Duro teve início por conta de um inventário redigido por Abílio Wolney, envolvendo terras e gado. Abílio Wolney ${ }^{45}$ tornou-se o advogado da viúva do fazendeiro Vicente de Pedro Belém ${ }^{46}$ e trabalhou na redação do inventário de bens do falecido. O documento foi apresentado ao juiz Manuel José de Almeida, que constatou algumas irregularidades, como a omissão de bens. O juiz

\footnotetext{
43 Esse foi um ponto destacado por David McCreery (2006) sobre a estrutura de poder em Goiás, na medida em que os grandes fazendeiros incorporavam bandidos e jagunços em suas milícias particulares e também, por serem os políticos da região, também na polícia. Ver: McCREERY, David, op. cit.

${ }_{44}^{4}$ ÉLIS, Bernardo. Veranicos de janeiro. Rio de Janeiro: José Olympio, 1979. p. 55.

${ }^{45}$ AIRES NETO, Abílio Wolney. O diário de Abílio Wolney. Anápolis: Edição do autor, 2002.

${ }^{46}$ Este foi assassinado em tocaia no dia 29 de dezembro de 1917. Ver: COELHO, Guilherme F. Expediçôes históricas nos sertôes de Goyaz: São José do Duro. Goiânia: ICBC, 2008.
} 
Sandro Dutra e Silva, Talliton Tulio Rocha Leonel de Moura e Francisco Itami Campos

não aceitou o documento, alegando não estar em sintonia com as normas da lei vigente. Ele argumentava que um montante de bens não havia sido arrolado, que Abílio Wolney e sua família tinham se apoderado deles, e os acusava de serem os mandantes do assassinato de Vicente Belém. Ao mesmo tempo, os Wolney acusavam o juiz, o coletor estadual Sebastião Brito e o delegado de polícia Joaquim Monteiro de Rezende de serem os mandantes do assassinato e quererem usurpar as suas posses.

Em tom de ameaça Abílio Wolney entrou na cidade com alguns jagunços e obrigou o juiz a aceitar o inventário. Após o acontecido, o juiz deixou a cidade, e o delegado de polícia do município enviou um telegrama ao chefe de polícia estadual e ao presidente do Estado, desembargador João Alves de Castro, pedindo intervenção estatal para averiguação dos crimes cometidos. Foram encaminhados cerca de 40 policiais juntamente com o juiz Celso Calmon para a resolução do conflito. Ao findar as investigaçóes, Celso Calmon decretou a prisão provisória de Abílio Wolney e de seu pai, o coronel Joaquim Ayres Cavalcante Wolney. $\mathrm{Na}$ tentativa de prisão dos acusados, o pai de Abílio foi assassinado pelos policiais por resistir à prisão. Os policiais invadiram a fazenda em que a família Wolney estava, capturaram os membros da família, homens e mulheres. Abílio Wolney conseguiu escapar da invasáo e se refugiou em uma outra fazenda da família, em que estavam acampados os jagunços e capangas da família. Os policiais prenderam o restante da família, tomados como reféns. As mulheres ficaram em prisão domiciliar e os homens foram presos ao tronco, antigo instrumento de prisão e tortura dos escravos. Qualquer ameaça de ataque do coronel do norte ao vilarejo do Duro os presos seriam executados.

Abílio Wolney atravessou a divisa do estado entrando na Bahia. Em contato com lideranças e aliados retornou para São José do Duro com aproximadamente 200 jagunços e cangaceiros, com vistas a recuperar o controle da vila das mãos dos policiais. Diante do ataque dos jagunços, todos os reféns presos no tronco foram mortos. O combate durou 3 dias, até que os policiais abandonaram a vila. ${ }^{47}$

Esse evento histórico apresenta-se como um caso marcante da condição de fronteira em Goiás. Aparentemente, ele teve início quando um coronel tentava se apropriar dos espólios de um pequeno fazendeiro falecido. Com a interferência do estado na questáo, o caso se transforma em um conflito armado entre as oligarquias do norte e sul de Goiás. Uma questâo política regional que tomou proporçóes de um violento conflito armado, envolvendo questôes agrárias e de dominação em Goiás. O domínio de terras, sobretudo de áreas ricas em pastagens, transformava a cobiça dos coronéis pecuaristas em Goiás em sangrentas disputas de poder.

\footnotetext{
${ }^{47}$ Esse episódio foi posteriormente transformado em romance pelo escritor Bernardo Élis. Ver: ÉLIS, Bernardo. O tronco. Rio de Janeiro: José Olympio, 2008.
} 
Sandro Dutra e Silva, Talliton Tulio Rocha Leonel de Moura e Francisco Itami Campos

Em uma carta escrita por Magalháes, em 20 de fevereiro de 1919, temos registros de um contemporâneo sobre a repercussão da chacina de São José do Duro em Goiás. O advogado relata que participou de reunião da Câmara de Vereadores de Pirenópolis em que notou a preocupação com a entrada de baianos (jagunços) em Goiás. Informava, ainda, que o intendente da vila de Espírito Santo do Peixe havia mobilizado uma postura municipal para interditar a entrada de cavaleiros vindos da Bahia. Na verdade, o relato tratava da presença de jagunços que aproveitavam o caos, imposto pela briga entre os coronéis do norte e do sul de Goiás, para cometer seus crimes. Magalhães assim relatou o contexto desse conflito e a sua repercussão em Pirenópolis, no sul do estado:

Por esses dias, foram chegando ao rancho do major, sujos e suarentos, uns soldados componentes da escolta que, segundo constava, havia assassinado toda a família Wolney. Esse rico fazendeiro estabelecido na Vila do Duro, norte do Estado, era odiado pelos políticos militares como adversário perigoso. A presença de uma expedição militar nesses desertos pôs em efervescência a jagunçada ociosa de aquém e além de Goiás. ${ }^{48}$

A fragmentação política e a dominação fundiária tornaram a fronteira goiana, desde o século XIX até a primeira metade do século XX, um território com precárias condições de controle público. Pedro Gomes de Oliveira, ${ }^{49}$ escrevendo na década de 1940, período que foi marcado pela inauguraçáo de Goiânia, a nova capital de Goiás, afirmava que o território goiano era uma "ficção geográfica". A tese de Oliveira se fundamentava na argumentação de que Goiás era um território sem o sentido de unidade. Até então, o sul e o sudoeste do estado ligavam-se a Minas Gerais; o nordeste goiano vinculava-se à Bahia; o norte goiano comercializava e se relacionava com o Maranhão e o Pará. A antiga capital, Cidade de Goiás, não expressava a unidade estadual, ficando isolada nas cercanias da Serra Dourada. Além disso, a falta de estradas e a dificuldade de comunicaçáo eram fatores que contribuíam para a não integração das regióes e para a falta de unidade territorial.

\section{A legislação de terras e a dominação fundiária}

As questôes agrárias e o processo de ocupação territorial em Goiás no século XX tiveram como característica marcante a dificuldade do acesso à propriedade pelos mais pobres. Este traço é evidenciado pelos recursos e meios usados pelos grupos dominantes. Além de uma legislação impeditiva, exigências burocráticas para a requisiçáo de terras foram estabelecidas, dificultando o acesso à terra pelos mais pobres e permitindo o apossamento pela classe

\footnotetext{
${ }^{48}$ MAGALHÃES, Carlos Pereira, op. cit., p. 51-52.

${ }^{49}$ OLIVEIRA, Pedro Gomes. O pito aceso. São Paulo: Revista dos Tribunais, 1942.
} 
Sandro Dutra e Silva, Talliton Tulio Rocha Leonel de Moura e Francisco Itami Campos

dirigente. Isto fez com que o preço da terra aumentasse. Embora proibido pela legislação imperial (Lei de Terras de 1850), o apossamento pelos poderosos se tornou a forma mais comum de ocupação no estado desde o século XIX.

A legislação de terra em vez de facilitar o acesso à terra, ao exigir a compra da propriedade, tornou inviável a sua própria aplicação. A legalização das terras, nas formas previstas, era desinteressante, tanto para a pecuária extensiva como para as lavouras de subsistência. A Constituição republicana de 1891 estabeleceu que as terras públicas deviam ser geridas pelos estados, e não mais pelo governo da república. As terras foram transferidas para os estados da federação, que, em sua maioria, desconheciam a extensão e a localização de suas terras devolutas.

Em razão da disposição constitucional em 1893 Goiás tem a sua primeira lei de terras. Esta lei estabelece que a forma de acesso à terra é a compra em hasta pública (Art. 1ํ), favorecendo a quem dispuser de dinheiro e procurando impedir a ocupação. Define como terras devolutas "as que não tiverem no domínio particular por título legítimo" e aquelas cujas posses não se fundarem em títulos capazes de legitimação ou reavaliação (Art. 13으). Uma definição que termina por abranger a todo o território estadual: todas as terras são públicas até prova em contrário. A lei estabelece como critérios preferência para venda: $1^{\circ}$ - maior lance; $2^{\circ}-$ pagamento à vista; $3^{-}$- cultura no terreno exposto à venda; $4^{\circ}$ - compra de maior número de lotes. (Art. 8o do Decreto) [...] Esse conjunto de normas será mantido nas diferentes legislaçóes de terra a partir de então. ${ }^{50}$

A legislaçáo goiana de 1893 apresentava as mesmas limitaçóes e impedimentos da legislação de 1850. Em 1897, entrou em vigor nova legislação de terras em Goiás, introduzindo algumas modificaçôes, como título provisório e aforamento, práticas comuns no apossamento das terras, e que foram mantidas ao longo da Primeira República (1889-1930). Destaque-se que a partir da primeira década do século XX, com a expansão da cafeicultura no sul do estado e com a chegada da ferrovia, ocorreu uma maior valorização das terras, gerando críticas por parte de governantes que passaram a reivindicar mudanças na legislação: "Em 1912 e 1913, o Executivo pede ao Congresso modificaçôes na legislação de terras, a fim de obstar a ação devastadora de particulares que estão se apropriando das terras devolutas". ${ }^{51}$

A partir das modificaçóes das medidas normativas, estipuladas pelo governo goiano no início da década de 1910, verificou-se uma preocupação maior dos órgãos públicos com o problema dos apossamentos, sendo que, desde o início da República, a lei de terras estipulava prazos para a legalização dos títulos. Porém, os prazos expiravam e os títulos não eram emitidos, o que gerava sérios problemas para a administração pública, tais como a venda de terras

\footnotetext{
${ }^{50}$ CAMPOS, F. Itami, 1985, op. cit., p. 97.

${ }^{51}$ Ibidem, p. 100.
} 
Sandro Dutra e Silva, Talliton Tulio Rocha Leonel de Moura e Francisco Itami Campos

de domínio particular pelo Estado e o desconhecimento real das áreas devolutas existentes. A partir da primeira década do século XX, ocorreu um surto de ocupação de terras, o que levou o governo estadual a fazer várias tentativas no sentido de regulamentar os títulos particulares. Por meio da Lei no 636 de 27 de julho de 1919, o governo goiano facilitou o registro de terras ocupadas, porém, essa medida não surtiu muito efeito, haja visto que, em 1925, novamente o executivo reclamava providências a fim de tornar possível o cadastramento de terras devolutas em função da pouca procura por registros.

O movimento revolucionário de 1930 colocou no poder, em Goiás, o grupo oposicionista liderado por Pedro Ludovico Teixeira, que assumiu como interventor, ficando no governo até 1945. Esse governo, no que diz respeito às políticas de imigração e colonização, teve como destaque, além da mudança da capital do estado, com construçáo iniciada em 1933 e localizada na região do Mato Grosso de Goiás,${ }^{52}$ a aceleração do processo de ocupação dessa região do estado. $\mathrm{O}$ incremento populacional evidenciava o fluxo migratório. Os dados do censo de 1920 indicavam uma populaçáo natural do estado em torno de 99,3\%, enquanto que os dados de 1940 mostravam que a população nativa era de 80,8\%, com 19,2\% de imigrantes. ${ }^{53}$

Além da construção da nova capital, outros fatores contribuíram para o surto migratório em Goiás, como o estímulo dado pelo governo para a ocupação de terras devolutas. Em 1935, foi promulgada a Lei $\mathrm{n}^{\circ}$ 52, que concedia para as famílias numerosas que migrassem para Goiás benefícios assistenciais e lotes de terras de 25 hectares, que deveriam ser demarcadas na região das Matas de São Patrício, na região do Mato Grosso de Goiás, no município de Jaraguá, estrategicamente localizadas próximo aos trilhos da ferrovia em Anápolis. Segundo Campos, essa legislação não chegou a ser efetivamente regulamentada e aplicada na época, mas teve um papel fundamental na divulgação da política de imigração goiana. A notícia de que em Goiás o governo estava doando terras atraiu para a região um grande número de novos colonos, e o estado passou a ser visto como um novo eldorado. ${ }^{54}$

Mesmo com o afluxo migratório, o interventor federal, em relatório ao presidente da república (1930-1933), criticou a legislaçâo em vigor (Lei no 124 de 1895), por considerá-la inadequada às condiçóes do estado, que era obrigado a dispensar recursos para a execução

\footnotetext{
${ }^{2} \mathrm{O}$ Mato Grosso de Goiás era um grande enclave florestal composto por floresta tropical estacional e que se manteve preservada até as primeiras décadas do século XX. A preservação dessa área deveu-se, em grande parte, à atividade da pecuária, que viam nos campos de Cerrado as gramíneas necessárias para a atividade. O custo em desmatar áreas de florestas densas, como o Mato Grosso de Goiás, tornava-se economicamente inviável. No entanto, a partir da expansão da fronteira agrícola, sobretudo a partir do início da construção de Goiânia em 1933 e da chegada da ferrovia em Anápolis em 1935, ocorreu a ocupação e desmatamento dessa área. Ver: FAISSOL, Speridiāo. O "Mato Grosso de Goiás". Rio de Janeiro: Instituto Brasileiro de Geografia e Estatística (IBGE); Conselho Nacional de Geografia, 1952; WAIBEL, Leo. Capitulos de geografia tropical e do Brasil. Instituto Brasileiro de Geografia e Estatística. Conselho Nacional de Geografia. Rio de Janeiro: IBGE, 1958; SILVA, Sandro Dutra e, 2013, op. cit.

${ }^{53}$ CAMPOS, F. Itami. 1985, op. cit.

${ }^{54}$ Idem.
} 
Sandro Dutra e Silva, Talliton Tulio Rocha Leonel de Moura e Francisco Itami Campos

da colonização. Para tanto, solicitava mudanças na lei, que deveria estar mais adequada às condiçôes regionais, eliminando "as pesadas obrigaçôes que a legislação anterior impunha aos cofres públicos, [...] procurando estimular a formação de núcleos coloniais" ${ }^{55} \mathrm{Em}$ 1935, o sistema de vendas de terras devolutas foi modificado por meio do Decreto-Lei no 313 de 1 de agosto, minimizando os trâmites burocráticos, abolindo os títulos provisórios e facilitando a compra. Com a instalação do Estado Novo, em 1937, a política de imigração e colonização passou ao controle do governo federal. Entretanto, não ocorreram modificaçôes na legislação de terras em Goiás, sendo que a regulamentação em vigor na época manteve-se até 1945.

Outro elemento importante na visualização do território e da expansão da fronteira é a forma como este território foi ocupado. $\mathrm{O}$ apossamento foi a forma comum de ocupação usada pelos senhores de gado e no desdobramento da frente agrícola, cuja atividade se articulava com a da pecuária. A Lei de Terras de 1850, proibindo o apossamento, pretendeu estabelecer a venda como único critério de aquisição da terra, contudo, pouco efeito produziu. Alguns autores já expuseram as consequências desta exigência. Em Goiás a prática do apossamento da terra continuou, embora a legislação proibisse. ${ }^{56}$

Destaque-se que, na república, a Constituição de 1891 transferiu aos estados a condição de legislar sobre a terra, tornando os estados administradores de imensa extensão de terras públicas. Até quase a década de 1960, as administraçôes estaduais desconheciam a extensão das terras devolutas, não sabendo também a sua localização. Essa condição favoreceu a prática do apossamento, permitindo a formação de latifúndios. Assim, "a maioria dos estabelecimentos pecuários não estava ao abrigo de qualquer título, além da mera ocupação, sendo escasso o interesse e muitas as dificuldades para a aquisição do domínio de terras". ${ }^{77}$

A partir dos anos 1930, passou a ocorrer um tipo de apossamento diferente, milhares de migrantes pobres se deslocaram, principalmente de Minas Gerais, para ocupar pequenos tratos de terra em Goiás. As condiçôes oferecidas permitiram a continuação do que Leo Waibel chama de agricultura migratória: "derrubar e queimar as matas, usar a terra durante alguns anos e depois mudar-se para outra mata a fim de recomeçar o mesmo ciclo". ${ }^{8}$

Os posseiros, após o desbravamento do Mato Grosso de Goiás, continuaram sua caminhada para o norte (Matas de São Patrício), onde foi implantada a Colônia Agrícola Nacional de Goiás (Cang, atualmente o município de Ceres), e seguiram ocupando e desmatando o médio-norte e o norte goianos. Esses posseiros detinham 20,8\% das propriedades

\footnotetext{
${ }^{55}$ Ibidem, p. 105.

${ }^{56}$ Sobre as questôes fundiárias em Goiás, ver: LUZ, Maria Amélia Alencar. Estrutura Fundiária em Goiás: Consolidação e Mudanças $(1850$ 1910). Goiânia: ICHL UFG, 1982; AGUIAR, Maria do Amparo Albuquerque. Terras de Goiás: estrutura fundiária (1850-1920). Goiânia, Ed. UFG, 2003.

${ }^{57}$ GUIMARÁES, Haroldo de Brito. O "Grilo” em Goiás: sua história, seus métodos e sua derrota. Revista de Direito, Goiânia, n. 9, 1973. p. 22.

${ }^{58}$ WAIBEL, Leo, op. cit., p. 335.
} 
Sandro Dutra e Silva, Talliton Tulio Rocha Leonel de Moura e Francisco Itami Campos

em 1940, tendo a sua participação ampliada em 1950 para 28,4\% das propriedades..$^{59}$ Os posseiros, longe de uma economia de mercado, afastados dos mecanismos de poder, desconhecendo a legislação de terras e distantes dos aparelhos de Estado, foram paulatinamente ocupando o território.

Quando as estradas tornaram possível o mercado, aquelas terras "sem valor" passaram a ter preços. Os novos donos chegaram, com títulos fornecidos pelo Estado ou com documentos falsificados. A questão era definir quem era o dono: o posseiro que trabalhava a terra há tempos, mas que não tinha documento, ou o fazendeiro/grileiro titulado. Esta foi a questão política central em Goiás nos anos 1950.

A grilagem pode ser entendida como uma forma de ocupação da terra valorizada.$^{60} \mathrm{~A}$ grilagem de terras, em Goiás, apareceu como fenômeno social nas décadas de 1940 e 1950, sobretudo a partir da construção de Brasília. Na região Norte houve maior incidência da grilagem, determinada quase que exclusivamente pela construção da rodovia Belém-Brasília. $\mathrm{Na}$ década de 1970, afirmou um senador, "temos quase que a metade do Estado atrofiado, sem nenhum desenvolvimento econômico, por culpa desses criminosos...” ${ }^{11}$ Ele se referia à impossibilidade de o norte goiano (regiáo acima do paralelo 13) receber os benefícios dos incentivos fiscais dados à Amazônia Legal. Não somente a região Norte foi objeto da ação dos grileiros. Anteriormente, também a regiáo sul de Goiás foi campo de ação da grilagem.

No início dos anos 1950, os grileiros têm defensores em diferentes níveis da administração pública - juízes de direito, promotores públicos, deputados estaduais, delegados de polícia: “... nos anos de maior prosperidade, a grilagem chegou a representar uma potência dentro do Estado, com ideólogos que traçaram sua doutrina, intelectuais que defenderam suas ideias e parlamentares que adotaram suas posiçōes”. ${ }^{62}$

No processo de ocupação, foram muitas as formas utilizadas por diferentes grupos para se estabelecer na terra. O que chama a atenção nessas ocupaçôes são os recursos e meios utilizados pelas elites dominantes para controlar a terra e impedir o trabalhador de ter acesso a ela. No controle da terra, observa-se a utilizaçáo de uma "legislaçáo impeditiva", pois as exigências burocráticas de requisição de terras, os levantamentos e demarcaçôes, dentre outras, além do preço, fizeram com que o acesso à terra fosse limitado aos senhores de gado, que assim expandiam seus rebanhos e suas terras. Além disso, o uso da violência sempre barrou o acesso à terra. A violência em diferentes formatos, dos capangas e mesmo da força pública, sempre esteve aliada às famílias dirigentes, senhores de terras e gado.

A prática da "grilagem" se tornou, a partir de um dado momento, uma forma efetiva de domínio da terra por setores dirigentes goianos. Embora sejam diversas as formas de ocu-

\footnotetext{
${ }^{59}$ CAMPOS, Francisco Itami, 2012, op. cit.

${ }^{60}$ KOTSCHO, Ricardo. O massacre dos posseiros. São Paulo: Brasiliense, 1982. p. 97.

${ }^{61}$ BRASIL. Senado Federal. Benedito FERREIRA. O "Grilo" no Planalto. Discursos. Brasília: Senado Federal, 1971. p. 43.

${ }^{62}$ GUIMARÁES, Haroldo de Brito, op. cit., p. 225.
} 
Sandro Dutra e Silva, Talliton Tulio Rocha Leonel de Moura e Francisco Itami Campos

pação, dois atores merecem referência - o fazendeiro/coronel ${ }^{63}$ e o camponês. Ainda que a legislação exigisse a compra como forma de ocupação, ela própria estabelecia condiçốes e exigências (burocracia e demarcaçóes) para a ocupação por aqueles que já detinham a posse da terra, estimulando o latifúndio.

Quando a legislação e a burocracia não eram suficientes para reprimir o acesso à terra, a violência era o recurso utilizado pelos latifundiários para reprimir a população que procurava um meio de sobrevivência nas terras devolutas. $\mathrm{O}$ movimento de repressão aos seguidores de Santa Dica, em 1925, por exemplo, evidencia a preocupação dos coronéis com camponeses e posseiros que participaram de um movimento de cunho messiânico em Goiás, movimento que teve relação com questôes fundiárias. Desde 1923, a fama de Benedita Cipriano Gomes, uma jovem de 16 anos que teria ressuscitado, percorria o sertáo goiano e reunia pessoas ao seu redor. Antes dos milagres de Santa Dica, codinome de Benedita, o vilarejo de Lagoa, próximo ao município de Pirenópolis, contava com apenas 12 casas. Em menos de dois anos a população do vilarejo subiu para mais de 500 pessoas e teve a visita, em média, de 60 mil romeiros. ${ }^{64}$

Santa Dica e os diqueiros, como eram conhecidos os seus seguidores, pregavam, além das curas e das questóes religiosas, a posse coletiva da terra. Eles tentaram criar um reduto, que foi intitulado de República dos Anjos, onde a propriedade da terra era coletiva. Inicialmente, Santa Dica e seus seguidores causaram problemas apenas para a Igreja Católica, por usurpar as funçôes clericais e desenvolver um catolicismo popular no interior de Goiás. O aumento populacional da República dos Anjos, no entanto, começou a perturbar setores dominantes da sociedade, que acusavam Dica de se apossar de fazendas particulares e temiam que o reduto viesse a se tornar uma sociedade paralela, como aquela organizada por Antônio Conselheiro em Canudos, no sertão baiano.

No dia 10 de agosto de 1925, o governo do estado de Goiás aceitou a denúncia dos coronéis de Pirenópolis e instalou um processo para julgar possíveis crimes e contravençóes que o reduto poderia estar causando. Para a averiguação das acusaçôes, foi decretada a prisão preventiva de Santa Dica. Quatro dias após a instalaçáo do processo, 80 policiais foram ao reduto prender a milagreira, resultando em um conflito armado, com 11 mortes. O caso de Santa Dica envolveu dois elementos dominantes da sociedade goiana: a Igreja Católica e os grandes latifundiários. Tanto a usurpação das funçôes da igreja como as questôes agrárias na "República dos Anjos" foram fatores que pressionaram o Estado a reprimir o movimento. A legislação vigente não permitia aquela aglutinação e temia o aumento daquele grupo. Em uma sociedade em que a violência era um fator cultural, o resultado obedecia à regra.

\footnotetext{
${ }^{63}$ Em Goiás o termo fazendeiro muitas vezes é aplicado tanto ao agricultor quando aos criadores de gado. Em comparação com o uso do termo em outras regiōes da América, a expressão "rancheiro" deveria ser a mais utilizada, pela vinculação desta com a atividade pecuária. Mas, tradicionalmente, aplica-se ao pecuarista o termo de fazendeiro, talvez por considerá-lo como proprietário de uma fazenda de gado.

${ }^{64}$ Ver: VASCONCELOS, Lauro de. Santa dica: encantamento do mundo ou coisa do povo. Goiânia: UFG, 1991.
} 
Sandro Dutra e Silva, Talliton Tulio Rocha Leonel de Moura e Francisco Itami Campos

Os posseiros foram reprimidos de diferentes formas no acesso à terra. Nos muitos conflitos de terras em Goiás, os posseiros tiveram contra si a força pública estadual, controlada pelos senhores de gado. Além disso, a ineficiência dos órgáos encarregados de controlar a terra pública desencadeou esse processo. Existia uma legislação de terras que não era aplicada, existia um departamento de terras que não funcionava e a conivência das autoridades com a ação da "grilagem".

\section{Considerações finais}

Como se formaram os latifúndios em Goiás? Esta foi a pergunta de um senador goiano, que ele mesmo respondeu, apresentando documentação da ação de políticos do estado. $\mathrm{O}$ senador concluiu afirmando: "as oligarquias mantêm-se no poder praticando influências, tomando terras, queimando ranchos, matando e expulsando posseiros, alargam desta forma seu poderio econômico". ${ }^{65}$

A legislaçáo de terras, Lei no 134, de 23/6/1897, e as que lhe substituíram são imprecisas quanto aos prazos e aos procedimentos para a legalização. No caso da lei de 1897, logo após a sua edição, muitas foram as críticas feitas por autoridades governamentais, contudo sem resultados práticos. Em 1904, em texto do Relatório da Secretaria de Obras Públicas do Estado de Goiás, a questão agrária reflete a dominação e a forma de apropriação das propriedades: "As terras do estado são em grande parte usufruídas por verdadeiros usurpadores que não se preocupam de legalizar os seus títulos." ${ }^{\text {"66 }}$ Além da falha da legislação, a administração estadual náo organizava o setor de venda da terra e nem controlava a sua ocupaçáo. Uma resposta clara para a indagação do senador pode ser encontrada no relato da questáo da terra que faz o governador Coimbra Bueno em 1949:

[...] O Regulamento de 1923 autorizava a venda de terrenos devolutos por meio de títulos provisórios, mediante a satisfação de precárias e insuficientes condiçôes. Estabelecia a área de 15.000 hectares para máximo de venda [...]. A frouxidáo do texto regulamentar, e a facilidade na expedição dos chamados títulos provisórios de domínio deram como resultado o seguinte: A maioria dos pretendentes requeria tratos enormes de terras, estimando sua área num mínimo possível e pagando o preço por esse mínimo. Recebia o título provisório, tomava posse de vastos latifúndios, e só requeria a medição quando as terras se valorizavam com a invasão de terceiros. A posse dessas vastas áreas permitia a seus titulares tornarem-se verdadeiros senhores

\footnotetext{
${ }^{65}$ BRASIL. Senado Federal. Henrique Santilo. Goiás... terras, grilos e dólares. Discursos. Brasília: Senado Federal, 1981. p. 25.

${ }^{66}$ GOIÁS. Relatório da Secretaria de Obras Públicas do Estado de Goiás, ano 1904.
} 
Sandro Dutra e Silva, Talliton Tulio Rocha Leonel de Moura e Francisco Itami Campos

feudais. Cobravam arrendamentos a pequenos lavradores que neles se fixassem, alienavam livremente tais terrenos e praticavam todos os atos de legítimos donos [...]. ${ }^{67}$

As teses da "ficção geográfica" e da "fronteira da fronteira" relacionam-se com os debates da fronteira como um território e uma condiçãa. Os elementos apresentados por Oliveira ${ }^{68}$ reforçam a falta de unidade e ao mesmo tempo os vazios administrativos, constituindo a fronteira goiana como um espaço ficcional. Já os argumentos de McCreery reforçam o isolamento, que, por sua vez, permite a emergência de estruturas próprias em decorrência dessa condição. Uma aproximação maior com a discussão de Hennessy e o contexto latino-americano, e, ao mesmo tempo, uma realidade distinta da concepçáo clássica da democrática presente na tese de Turner. O historiador Arthur Lima de Ávila ${ }^{69}$ entende que a tese de Turner se fundamenta na existência de free lands no oeste, o que atraía colonos em busca de novas oportunidades. A relação entre sociedade e natureza na tese de Turner fundava as bases para a democracia americana. De acordo com Ávila:

[...] afastados da civilização e em contato com a natureza intocada (a wilderness), eles eram livres para perseguir a tão sonhada igualdade econômica e política - não existia nenhum entrave à ascensão do homem comum ao topo da pirâmide social, a não ser sua própria fraqueza. [...] Além disso a wilderness era responsável pela americanização do colono: sua identidade europeia era deixada para trás e ele renascia como o homo americanos, um novo ente cultural (eticamente europeu, mas culturalmente mestiço) completamente adaptado ao Novo Mundo. Era este choque dialético entre "selvageria" (o espaço natural) e "civilização" (o homem branco da fronteira - o pioneer) que surgia o excepcional regime democrático da América. ${ }^{70}$

A fronteira goiana, seja em relação ao espaço ficcional da região ou no distanciamento e no isolamento em relação a outras regióes brasileiras, não foi um lugar que permitiu a emergência dos valores próprios da democracia. Ao contrário, fortaleceu os processos relacionais nos domínios do latifúndio. Tratava-se de uma dominação que se exercia não apenas na posse da terra, mas também nas relaçóes sociais. Também, considerando a tese clássica de Martins, ${ }^{71}$ identificamos na fronteira goiana, a partir das relaçóes fundiárias, os processos de desumanização do outro. Compreendemos, no entanto, que essa discussão não se encerra nos argumentos propostos neste artigo, na medida em que a temática aponta para assuntos variados que poderiam ser ainda mais bem explorados. No entanto, procuramos destacar

\footnotetext{
${ }^{67}$ GOIÁS. Governador Coimbra Bueno, Mensagem à Assembleia Legislativa, 1949, p. 50.

${ }^{68}$ OLIVEIRA, Pedro Gomes, op. cit.

${ }^{69}$ ÁVILA, Arthur Lima, op. cit.

${ }^{70}$ Ibidem, p. 85.

${ }^{71}$ MARTINS, José de Sousa. Fronteira: a degradação do outro nos confins do humano. São Paulo: Hucitec, 1997.
} 
Sandro Dutra e Silva, Talliton Tulio Rocha Leonel de Moura e Francisco Itami Campos

os processos relacionais que envolviam a dominação fundiária na fronteira e a sua carga de violência (simbólica e real).

$\mathrm{O}$ isolamento da fronteira goiana, nesse sentido, vai além da ficção geográfica e os debates em torno do sentido da unidade territorial. Essa fragilidade territorial encontra amparo na tese de McCreery sobre a "fronteira da fronteira". Nesse sentido, a pecuária não pode ser interpretada como a gênese da ritualização da violência, mas como uma condição de fronteira, na qual os criadores de gado eram os donos do poder. Essa ritualização da violência naturalizada constituía os traços culturais do ethos da fronteira em Goiás. Parafraseando Magalhães, ${ }^{72} \mathrm{em}$ Goiás matar um boi no matadouro era tão natural quanto matar um sertanejo no cerrado.

A cattle frontier em Goiás se insere como um caminho interpretativo da relação entre história e natureza no Oeste do Brasil. Ela incorpora a cultura pastoril e os elementos do distante oeste que se relacionam com essa atividade, como o isolamento, a violência e a dominação fundiária que marcavam a fronteira goiana. Muito mais do que apenas descrever a atividade pastoril, a fronteira do gado deve ser compreendida no conjunto de temas que os historiadores têm à sua disposição, seguindo as orientações deixadas por Donald Worster ${ }^{73}$ de que os desafios e as abordagens são imensos sob o céu do grande oeste.

\section{Fontes documentais}

BRASIL. Senado Federal. Benedito Ferreira. O “Grilo” no Planalto. Discursos. Brasília: Senado Federal, 1971. p. 43.

BRASIL. Senado Federal. Henrique Santilo. Goiás... terras, grilos e dólares. Discursos. Brasília: Senado Federal, 1981. p. 25.

GOIÁS. Governador Coimbra Bueno, Mensagem à Assembleia Legislativa, 1949.

GOIÁS. Relatório da Secretaria de Obras Públicas do Estado de Goiás, ano 1904.

\section{Referências bibliográficas}

AGUIAR, Maria do Amparo Albuquerque. Terras de Goiás: estrutura fundiária (18501920). Goiânia: Ed. UFG, 2003.

AIRES NETO, Abílio Wolney. O diário de Abilio Wolney. Anápolis: Edição do Autor, 2002. ÁVILA, Arthur Lima. Da história da fronteira à história do Oeste: fragmentação e crise na Western history norte-americana no século XX. História Unisinos, v. 13, n. 1, p. 78-83, jan./ abr. 2009.

\footnotetext{
${ }^{72}$ MAGALHÃES, Carlos Pereira, op. cit.

${ }^{73}$ WORSTER, Donald, op. cit.
} 


\section{A terRa dos CORONÉIS NO OESTE DO BRASIL: \\ A CATTLE FRONTIER, VIOLÊNCIA E DOMINAÇÃO FUNDIÁRIA NO CERRADO GOIANO}

Sandro Dutra e Silva, Talliton Tulio Rocha Leonel de Moura e Francisco Itami Campos

BELL, Stephen. Campanha Gaúcha: a Brazilian Ranching System, 1850-1920. Stanford: Stanford University Press, 1998.

BORGES, Barsanufo G. O despertar dos dormentes. Goiânia: Ed. UFG, 1980.

BRASIL, Antônio Americano do. Súmula de História de Goiás. 3. ed. Edição anotada por Humberto Crispim Borges. Goiânia: Unigraf, 1982.

CAMPOS, F. Itami. Questão agrária: bases sociais da política goiana (1930-1964). Tese (Doutorado em Ciências Políticas) — Departamento de Ciências Sociais, Universidade de São Paulo, USP, São Paulo, 1985.

. Coronelismo em Goiás. 2. ed. Goiânia: Vieira, 2005.

. Questóes agrárias: bases sociais da política goiana. Goiânia: Kelps, 2012.

CAMPOS, Francisco Itami; Sandro Dutra e. Coronéis e camponeses: a fronteira da fronteira e a tese da "ficção geográfica" em Goiás. In: SILVA, Sandro Dutra; PIETRAFESA, José Paulo; FRANCO, José Luiz de Andrade; DRUMMOND, José Augusto; TAVARES, Giovana Galvão (Org.). Fronteira Goiás: sociedade e natureza no Oeste do Brasil. Goiânia: Ed. da PUC Goiás, 2013.

CHAUL, Nasr Fayad. Coronelismo em Goiás: estudo de casos e famílias. Tese (Mestrado em História). Goiânia: Kelps, 1998.

COELHO, Guilherme F. Expediçôes históricas nos sertôes de Goyaz: São José do Duro. Goiânia: ICBC, 2008.

COSTA, Odorico. A pecuária goiana. Cultura Política: revista mensal de estudos brasileiros, Rio de Janeiro, ano IV, n. 46, p. 257-268, nov. 1944.

CRONON, William. Uncommon Ground: Rethinking the Human Place in Nature. Nova York/Londres: W. W. Norton \& Company, 1996.

ÉLIS, Bernardo. Veranicos de Janeiro. Rio de Janeiro: José Olympio, 1979.

- O tronco. Rio de Janeiro: José Olympio, 2008.

FAISSOL, Speridião. O "Mato Grosso de Goiás". Rio de Janeiro: Instituto Brasileiro de Geografia e Estatística (IBGE); Conselho Nacional de Geografia, 1952.

GUIMARÃES, Haroldo de Brito. O “Grilo” em Goiás: sua história, seus métodos e sua derrota. Revista de Direito, n. 9. Goiânia: Procuradoria Geral do Estado de Goiás, 1973.

HENNESSY, Alistair. The Frontier in Latin American History. Londres: Edward Arnold, 1978.

KOTSCHO, Ricardo. O massacre dos posseiros. São Paulo: Brasiliense, 1982.

LUZ, Maria Amélia Alencar. Estrutura fundiária em Goiás: consolidação e mudanças (1850 1910). Goiânia: ICHL UFG, 1982.

MAGALHÃES, Carlos Pereira de. Cartas de Goiás no princípio do século XX. São Paulo: Editora de Letra em Letra, 2004. 
Sandro Dutra e Silva, Talliton Tulio Rocha Leonel de Moura e Francisco Itami Campos

MARTINS, José de Sousa. Fronteira: a degradação do outro nos confins do humano. São Paulo: Hucitec, 1997.

McCREERY, David. Frontier Goiás, 1822-1889. Stanford: Stanford University Press, 2006. NASH, Roderick Frazier. Wilderness and the American Mind. New Haven/Londres: Yale University Press, 1982.

OLIVEIRA, Lucia Lippi. Americanos: representaçôes da identidade nacional no Brasil e nos EUA. Belo Horizonte: Editora UFMG, 2000.

OLIVEIRA, Pedro Gomes. O pito aceso. São Paulo: Revista dos Tribunais, 1942.

PALACÍN, Luis. Coronelismo no extremo norte de Goiás: o padre João e as três revoluçóes de Boa Vista - Tocantinópolis. São Paulo: Ediçốes Loyola, 1990.

. O século do ouro em Goiás: 1722-1822, estrutura e conjuntura numa capitania de Minas. Goiânia: Ed. da UCG, 1994.

SAINT-HILAIRE, Auguste de. Viagem às nascentes do rio São Francisco. Belo Horizonte: Itatiaia, 2004.

- Viagem à provincia de Goiás. Belo Horizonte: Itatiaia; São Paulo: Editora da Universidade de São Paulo, 1975.

SILVA, Sandro Dutra e. Os estigmatizados: distinçôes urbanas às margens do rio das Almas em Goiás (1941-1959). Tese (Doutorado em História) — Programa de Pós-Graduação em História. Universidade de Brasília, Brasília, 2008.

- O desbravador do Oeste: categorias e símbolos referenciais para a colonização de Goiás na Era Vargas. In: MARIN, Joel Orlando Bevilaqua; NEVES, Delma Pessanha (Org.). Campesinato e marcha para Oeste. Santa Maria, RS: Editora UFSM, 2013.

SMITH, Henry Nash. Virgin Land: the American West as Symbol and Myth. Cambridge, Massachusetts/Londres: Harvard University Press, 2009.

SOUZA, Dalva Maria Borges de Lima Dias de. Violência, poder e autoridade em Goiás. Goiânia: Editora UFG, 2006.

TURNER, Frederick Jackson. The frontier in American history. Mineola, Nova York: Dover Publications, 2010.

VASCONCELOS, Lauro de. Santa dica: encantamento do mundo ou coisa do povo. Goiânia: UFG, 1991.

WAIBEL, Leo. Capitulos de geografia tropical e do Brasil. Instituto Brasileiro de Geografia e Estatística. Conselho Nacional de Geografia. Rio de Janeiro: IBGE, 1958.

WEBB, Walter Prescott. The great frontier. Reno, Las Vegas: University of Nevada Press, 2003.

WORSTER, Donald. Under Western Skies: Nature and History in the American West. Nova York: Oxford University Press, 1992. 